\title{
Menangkal Paham Radikal di Sekolah
}

\author{
Oleh Fathurozi \\ Staf Balai Penelitian dan Pengembangan Agama Semarang
}

Pendidikan Agama (PA) yang diajarkan di sekolah berisi materi tentang ritual ibadah keagamaan. Namun kurang membahas hubungan antar umat beragama. Tak ayal jika anak didik kurang menghormati pemeluk agama lain, sehingga terjadi menumbuhkan bibit-bibit kebencian.

Materi agama yang diajarkan di sekolah kurang menyentuh hubungan antarumat beragama.

Namun tidak mudah untuk mengajarkan nilai-nilai tolerasi pada siswa. Bahkan buku-buku yang membahas nilai-nilai tolerasi dan multikultural diperpustakaan sekolah kurang memadai. Padahal buku yang di baca siswa sering kali dijadikan acuan dalam bersikap dan bertindak.

Kelihatanya telah terjadi pergeseran dalam kegiatan belajar, sementara siswa hanyalah sebagai objek, sehingga apa yang diajarkan oleh gurunya itu yang paling benar dan dipraktekan pada kehidupan sehari-hari. Ironis memang, jika siswa menemukan sesutau yang berbau radikal, siswa tak berani menyampaikan pada sang guru.

Padahal pendidikan agama diharapkan dapat membentuk peserta didik sebagai generasi terpelajar yang memiliki kecerdasan kognitif melalui pengetahuan umum dan pengetahuan keterampilan serta memiliki kecerdasan emosional dan spiritual.

Berdasarkan Survei Lembaga Kajian Islam dan Perdamaian (LaKIP), yang dipimpin oleh Prof Dr Bambang Pranowo, yang juga guru besar sosiologi Islam di UIN Jakarta, pada Oktober 2010 hingga Januari 2011, mengungkapkan hampir 50\% pelajar setuju tindakan radikal. Sedangkan $25 \%$ siswa dan $21 \%$ guru menyatakan Pancasila tidak relevan lagi. Kemudian $52,3 \%$ menyatakan setuju dengan kekerasan untuk solidaritas agama.

Melemahnya nilai persaudaraan, menguatnya nasionalisme kesukuan, aksi tawuran antar kampung, bentrok kelompok masyarakat karena perbedaan keyakinan, sampai pada aksi teror yang menggunakan isu agama sebagai legalitas moralnya adalah bukti lemahnya identitas moral. Sehingga siswa rela melakukan kekerasan, padahal menyalahi hak-hak hidup individu dan kelompok lain.

\section{Menangkal Radikalisasi}

Pengajaran PA bersifat privat dari sini lah pemerintah menyediakan guru agama Islam, Kristen, Katolik, Hindu, Budha dan Khong $\mathrm{Hu} \mathrm{Cu}$. Namun yang terjadi guru mengajarkan seputar memahami dan mengamalkan nilai-nilai ajaran agamanya. Sehingga siswa kurang bisa menghargai perbedaan keyakinan.

Dalam buku berjudul "Pendidikan Pasca konflik, Pendidikan Multikultural Berbasis Konseling Budaya Masyarakat Maluku Utara" Karya Dr. M. Tahir Sapsuha (2013). Pendidikan agama kurang menyentuh pengembangan sosial dan horisontal karena materi yang diajarkan sekadar Iman, Ibadah dan etika dalam pendidikan agama Islam, serta pengetahuan tentang sejarah gereja, iman Kristen, dan etika kristiani dalam 
pendidikan Agama Kristen lebih menekankan pada dogma-dogma agama masingmasing.

Menurut Tahir lagi, pengajaran seperti ini menjadikan agama kelihatan tidak ramah dan ada kecenderungan kekerasan atas nama agama wajib hukumnya. Bila merujuk PP Nomor 55 Tahun 2007 Bab II Pasal 2, "Pendidikan agama berfungsi membentuk manusia Indonesia yang beriman dan bertakwa kepada Tuhan Yang Maha Esa serta berakhklak mulia dan mampu menjaga kedamaian serta kerukunan inter dan antaragama. Namun di lapangan sekolah kurang menerapkannya.

Sejatinya PA bisa digunakan sebagai filter moral bagi anak didik ketika bergaul dengan teman di sekolah ataupun di rumah. Sehingga membentuk karakter manusia berakhlak mulia.

Namun orang tua kurang kontrol terhadap perubahan si anak, mungkin saja para wali murid tak perlu mengajarkan agama di rumah karena sudah mendapatkan agama dari sekolah.

Dough Monk dalam penelitiannya di Humble Texas menemukan bahwa kurikulum sekolah yang lebih banyak mengajak murid untuk berinteraksi dalam kegiatan-kegiatan sosial dan mengembangkan kepekaan mereka, telah memberikan dampak positif dalam perubahan belajar, kepedulian dan rasa hormat kepada staf sekolah serta keterlibatan para siswa secara sukarela dalam proyek-proyek kemanusiaan (Brooks 2005).

Perubahan paradigma dan performa para pelaku pendidikan dalam hal ini guru agama baik dari segi orientasi, isi maupun metodologi mengarahkan anak didik pada tugas rumah untuk mengamati prilaku sosial keagamaan dilingkungan tempat tinggal dan guru memberikan jawaban semaksimal mungkin.

Hal ini akan meransang anak didik berfikir, daripada hanya menerima materimateri terus menerus tanpa dipraktekkan dilapangan.

Pelajaran agama sebaiknya mengacu pada perubahan realita sosial dikalangan masyarakat. Menangkal radikalisasi tidak semata-mata tugas pendidik melainkan tugas kita bersama.

Masyarakat bisa ikut andil dengan cara menghidupkan kembali tradisi lokal seperti gotong royong sehingga akan menciptakan kehidupan masyarakat yang damai dan harmonis di tengah perbedaan.

Dimuat Radar Tegal, 20 Juli 2018 